\title{
MONITORING PERUBAHAN AREAL PERSAWAHAN MENGGUNAKAN APLIKASI SISTEM INFORMASI GEOGRAFIS (Studi Kasus: Kecamatan Pallangga Kabupaten Gowa)
}

\author{
Landuse Changes Monitoring of Paddy Field based on A Geographic Information System \\ (Case Study: Pallangga District, Gowa Regency) \\ ${ }^{1 *}$ Magfirah Djamaluddin, ${ }^{1}$ Andi Ramlan, ${ }^{1}$ Muh. Jayadi \\ ${ }^{1}$ Departemen Ilmu Tanah, Fakultas Pertanian, Universitas Hasanuddin \\ *Corresponding email: firah.djamal@gmail.com
}

\begin{abstract}
The area of agricultural land, especially paddy fields, is related to the level of rice production. Conversion of agricultural land to non-agriculture will have an impact on the availability of rice supply. This study aims to identify changes in paddy field land use in 2005 - 2016 using high-resolution satellite imagery and calculate the need for rice per capita in Pallangga District. This research utilizes the application of geographic information systems in monitoring changes in paddy field use. The method used in the classification of land use is digitizing on screen. The conversion of paddy fields to non-paddy fields was obtained from the results of overlapping maps of Pallangga District land use maps in 2005 and 2016 and presented in the form of cross tabulations. The accuracy test results obtained the overall accuracy value of $98.04 \%$, and the kappa accuracy value of 0.98 . This study shows that paddy field area has decreased by 305.25 ha. The change consisted of 17.68 ha into a water body, turned into a garden of 132.86 ha and became a settlement of 154.71 ha. The conversion of paddy fields in Pallangga District in 2005-2016 affected rice production. The results of the analysis of the needs of rice per capita per year show that in 2017 Pallangga District is surplus in the supply of rice to its population. However, based on population projection, the decrease in land area and rice
\end{abstract}

production in Pallangga Subdistrict in 2020 was unable to meet the rice needs of its population of 1,027 tons.

Keywords: geographic information system, local food security, monitoring, paddy fields.

\section{PENDAHULUAN}

Permintaan terhadap beras dari tahun ketahun cenderung meningkat sejalan dengan laju peningkatan jumlah penduduk. Sementara produksi padi dalam beberapa tahun terakhir menunjukkan gejala melandai. Pelandaian produksi tersebut terjadi pada beberapa daerah di Indonesia. Berdasarkan hasil penelitian yang dilakukan oleh Sulistyawati (2014), penurunan produksi padi dalam kurun waktu 10 tahun (2004 - 2013) di Kabupaten Cianjur Jawa Barat sebesar 33.172,15 ton. Penurunan ini diakibatkan oleh adanya alih fungsi lahan sawah menjadi penggunaan lahan lain.

Penurunan produksi padi terjadi pula di Kabupaten Gowa. Kabupaten Gowa pada tahun 2014 memiliki luas panen lahan sawah sebesar 61.139 ha. Luas panen lahan sawah terbesar terdapat di Kecamatan Pallangga seluas 5.540 ha atau sekitar 9,06 \% luas panen lahan sawah di Kabupaten Gowa. Berdasarkan data statistik tanaman pangan dan palawija tahun 2015, produksi padi sawah tahun 2015 mengalami 
penurunan sebesar $5,73 \%$, yaitu dari 309.909 ton pada tahun 2014 menurun menjadi 292.156 ton pada tahun 2015. Hal tersebut mengindikasikan bahwa terdapat pengurangan volume produksi gabah setara beras sebesar 11.141,37 ton pada tahun 2015. Berdasarkan pada laporan kinerja Pemerintah Kab. Gowa pada tahun 2014 bahwa salah satu faktor yang menjadi kendala peningkatan produktivitas dan produksi pangan di Kabupaten Gowa adalah tingginya konversi lahan produktif ke lahan non pertanian tanaman pangan

Monitoring atau pemantauan penggunaan lahan pada suatu daerah sangat penting dilakukan agar dapat mencegah adanya masalah ruang untuk hidup yang timbul karena masyarakat salah dalam memanfaatkan lahan. Dalam penelitian ini teknologi penginderaan jauh digunakan dalam memonitoring perubahan penggunaan lahan sawah (Sinaga, 2004). Adanya alih fungsi lahan pertanian, khususnya pada lahan sawah, akan mempengaruhi produksi beras yang merupakan bahan makanan pokok masyarakat Indonesia (Sulistyawati, 2014).

Jika hal ini dibiarkan terus-menerus akan berpengaruh pada ketahanan pangan. Badan Ketahanan Pangan Kementerian Pertanian menetapkan angka konsumsi beras Indonesia sebesar 139,15 $\mathrm{kg} / \mathrm{kapita} / \mathrm{tahun}$. Jika alih fungsi lahan sawah terus menerus terjadi di Kecamatan Pallangga, maka konsumsi beras per kapita penduduk tidak akan terpenuhi. Hal ini mengindikasikan bahwa kebutuhan beras harus disuplai dari daerah lain.

Berdasarkan hal tersebut maka perlu dilakukan penelitian untuk mengidentifikasi perubahan penggunaan lahan sawah tahun 2005 - 2016 menggunakan citra satelit resolusi tinggi dengan memanfaatkan teknologi penginderaan jauh. Apakah konversi lahan sawah yang terjadi berdampak terhadap ketahanan pangan di Kecamatan Palangga.

\section{METODOLOGI}

Penelitian ini dilaksanakan di Kecamatan Pallangga, Kabupaten Gowa, Provinsi Sulawesi Selatan. Perangkat analisis yang digunakan yaitu aplikasi pemetaan ArcGis 10.3, GPS (Global Position system) dan kamera. Data yang digunakan ditampilkan pada Tabel 1.

Tabel 1. Data dan sumber data penelitian

\begin{tabular}{|c|c|c|c|c|}
\hline $\mathrm{N}_{0}$. & Bahan & Sumber Data & Tahun & Skalalaresolusi \\
\hline 1. & $\begin{array}{l}\text { Citra Satelit Resolusi } \\
\text { Tinggi }\end{array}$ & $\begin{array}{l}\text { Google Earth } \\
\text { (Digital Globe) }\end{array}$ & $\begin{array}{l}2005 \text { dan } \\
2016\end{array}$ & $0,6 \mathrm{mx} 0,6 \mathrm{~m}$ \\
\hline 2. & $\begin{array}{l}\text { Peta admistrasi } \\
\text { Kecamatan Pallangga }\end{array}$ & $\begin{array}{l}\text { BAPPEDA } \\
\text { Kabupaten Gowa }\end{array}$ & 2012 & $1: 50.000$ \\
\hline 3. & $\begin{array}{l}\text { Data monografi } \\
\text { Kecamatan Pallangga }\end{array}$ & $\begin{array}{l}\text { BPS Kabupaten } \\
\text { Gowa }\end{array}$ & $2005-2016$ & \\
\hline 4. & $\begin{array}{l}\text { Pola muang RTRW } \\
\text { Kabupaten Gowa }\end{array}$ & $\begin{array}{l}\text { BAPPEDA } \\
\text { Kabupaten Gowa }\end{array}$ & $2012-2032$ & $1: 50.000$ \\
\hline
\end{tabular}

\section{Prosedur Penelitian}

Adapun prosedur penelitian dilaksanakan dengan tahapan sebagai berikut:

\section{Pengumpulan Data}

Penyiapan dan pengumpulan data yang dilaksanakan terdiri atas:

1. Data primer yaitu data citra resolusi tinggi tahun 2005 dan 2016 serta data yang dikumpulkan atau diperoleh dari hasil wawancara maupun pengamatan langsung dilapangan.

2. Data sekunder yaitu data yang bersumber dari studi kepustakaan atau sumber lain yang terpercaya.

\section{Tahap Analisis Data}

1. Proses pra-pengolahan Citra

Pra-klasifikasi citra meliputi proses koreksi geometrik dan pemotongan citra (Image Cropping).

\section{Koreksi Geometrik}

Tujuan dari koreksi geometris adalah menghasilkan data penginderaan jauh yang sesuai dengan kondisi koordinat sebenarnya dipermukaan tanah. 
Ketelitian koreksi geometrik ditentukan oleh nilai RMSE (Root Mean Square Error). Semakin kecil nilai RMSE, berarti semakin teliti penentuan GCP di citra. Besarnya nilai RMSE sebaiknya di bawah 0,5 (Jensen, 1986 dalam Hidayati 2013). RMSE dihitung dengan persamaan:

$$
\operatorname{RMSE}=\sqrt{\left(x^{\prime}-x\right)^{2}+\left(y^{\prime}-y\right)^{2}}
$$

dimana, $x^{\prime}$ dan $y^{\prime}$ adalah koordinat titik pada citra acuan, $x$ dan $y$ adalah koordinat titik pada citra yang akan dikoreksi.

\section{Image Cropping}

Cropping bertujuan untuk membatasi daerah penelitian dengan daerah yang bukan daerah penelitian. Pembatasan wilayah studi pada citra menggunakan batas administrasi dengan memakai tools image analysis pada ArcGis 10.3.

\section{Interpretasi Visual Citra Satelit}

Analisis visual (interpretasi secara visual citra satelit) merupakan suatu kegiatan untuk mendeteksi dan mengidentifikasi objek-objek yang ada di permukaan bumi yang tampak pada citra lalu kemudian diklasifikasikan kedalam masing-masing kelas tutupan dan penggunaan lahan tertentu. Dalam proses klasifikasi dengan menggunakan citra resolusi tinggi dilakukan dengan cara mendigitasi secara manual berdasarkan kenampakan pada layar komputer (digitasi on screen).

\section{Pengecekan Lapangan (ground truth)}

Pengecakan lapangan dimaksudkan untuk mengecek kebenaran peta hasil klasifikasi citra terutama pada lokasi meragukan. Metode pengambilan sampel yang digunakan yaitu stratified random sampling. Pemilihan metode ini mengacu pada kelebihannya, dimana setiap strata/kelas penutup lahan mempunyai alokasi sampel untuk evaluasi akurasi, walau proporsi kelas tersebut kecil dalam daerah penelitian (Jensen, 2005 dalam Khoiriah 2012). Congalton dalam Green et al., (2000), merekomendasikan jumlah titik sampel untuk setiap kategori penutup lahan atau penggunaan lahan adalah 50 titik. Khorram dan Morisette (2000) menggunakan 100 titik sampel per kelas untuk 15 kelas penutup lahan. Jumlah sampel dalam penelitian ini mengacu pada Congalton (1991) dalam Green et al., (2000) yaitu 50 sampel dalam setiap penutup lahan.

\section{Evaluasi Akurasi}

Evaluasi ini menguji tingkat keakuratan secara visual dari hasil klasifikasi menggunakan teknik digitasi on screen dengan menggunakan titik-titik kontrol lapangan. Pengujian ketelitian hasil klasifikasi dilakukan dengan teknik confusion matrix (matrik kesalahan). Metode ini dilakukan dengan membandingkan citra hasil klasifikasi sebagai dasar kelas yang sebenarnya dengan beberapa data lapangan yang diyakini secara akurat mewakili suatu penggunaan lahan.

Analisis kappa digunakan untuk menghitung nilai akurasi klasifikasi dari confusion matrix. Analisis kappa menghasilkan nilai koefisien kappa yang memiliki rentang kemungkinan dari 0 hingga 1 (Green et al., 2000). Nilai koefisien kappa dapat dihitung melalui persamaan berikut:

$$
K=\frac{N \sum_{i=1}^{r} X_{i i}-\sum_{i=1}^{r}\left(X_{i+} \cdot X_{+i}\right)}{N^{2}-\sum_{i=1}^{r}\left(X_{i+\cdot} \cdot X_{+i}\right)}
$$

dimana, $K$ adalah Koefisien akurasi, $\mathrm{r}$ adalah jumlah baris dalam matriks, $X_{i i}$ adalah pixel pada diagonal utama confusion matrix, $\mathrm{X}_{i+}$ adalah jumlah pixel seluruh kolom pada suatu baris, $\mathrm{X}_{+i}$ adalah jumlah pixel seluruh baris pada suatu kolom dan $\mathrm{N}$ adalah jumlah seluruh pixel sampel dalam confusion matrix. 
7. Analisis Peta Sebaran Lahan Persawahan Tahun 2005 dan 2016

Analisis laju konversi lahan sawah ditelaah dengan membandingkan luasan sawah tahun 2005 dan luasan sawah tahun 2016 dengan cara tumpan susun peta penggunaan lahan hasil interpretasi citra tahun 2005 (Gambar 1) dan tahun 2016 (Gambar 2). Hasil dari proses tumpang susun tersebut disajikan dalam bentuk tabulasi silang untuk memudahkan dalam proses penentuan dalam menunjukkan wilayah-wilayah yang tetap dan mengalami perubahan penggunaan lahan. Analisis tabulasi silang sangat bermanfaat dalam mendeskripsikan perubahan penggunaan lahan sawah dan memberikan informasi tentang persentase jumlah luasan sawah dari tahun 2005-2016 serta total konversi lahan sawah yang menjadi kelas penggunaan lahan lain.

\section{Analisis Kebutuhan Pangan Kecamatan Pallangga}

Untuk permasalahan yang dibahas mengenai ketahanan pangan dalam penelitian ini mengacu pada ketersediaan pasokan beras tahun 2016, apakah mencukupi penduduk Kecamatan Pallangga untuk tahun 2017. Pengukuran kebutuhan beras per kapita menggunakan rumus yaitu hasil bagi antara jumlah produksi beras (ton) dengan jumlah penduduk (jiwa), dalam penelitian ini kebutuhan beras per kapita dihitung melalui persamaan berikut:

$$
K=\frac{O \times V}{U}
$$

dimana, $K$ adalah kebutuhan beras/kapita/tahun, $O$ adalah hasil produksi padi dalam satuan ton, $U$ adalah jumlah penduduk, dan $V$ adalah nilai konversi padi ke beras sebesar $62,74 \%$.

Hasil dari pengolahan data mengenai kebutuhan beras per kapita kemudian dibandingkan dengan angka ketetapan dari Badan Ketahanan Pangan Kementerian Pertanian sebesar 139,15 $\mathrm{kg} / \mathrm{kapita} / \mathrm{tahun} \quad$ atau $\quad 0,14$ ton/kapita/tahun. Dengan diperolehnya angka tersebut akan menunjukan bahwa kebutuhan beras per kapita di Kecamatan Pallangga apakah mampu mencukupi kebutuhan beras rata-rata per kapita sebesar 0,14 ton yang telah menjadi angka ketetapan dari Badan Ketahanan Pangan Kementerian Pertanian.

Ketahanan pangan lokal yang dihitung dalam penelitian ini hanya dengan asumsi bahwa masyarakat di Kecamatan Pallangga hanya mengkonsumsi beras sebagai makanan pokok. Untuk perhitungan kebutuhan beras dengan asumsi bahwa jumlah produksi beras tahun 2016 diperoleh dari hasil proyeksi luas panen dan produksi beras menurut klasifikasi citra berdasarkan produktivitas dari data statistik pertanian BPS.

Sebelum menentukan luas panen, terlebih dahulu dicari rasio dari luas panen sawah terhadap luas lahan sawah berdasarkan data statistik BPS. Cara penentuan proyeksi luas panen sawah menurut citra berdasarkan data statistik pertanian BPS yaitu dengan menentukan rasio antara luas panen dan luas lahan sawah menurut data BPS terlebih dahulu dengan cara berikut:

$$
f=\frac{L P}{L T}
$$

dimana, $f$ adalah rasio luas panen dan luas lahan sawah menurut BPS, $L P$ adalah luas panen sawah menurut BPS (ha), dan $L T$ adalah luas lahan sawah menurut BPS (ha). Setelah rasio antara luas panen dan luas lahan sawah menurut BPS telah ditentukan, maka dapat ditentukan luas panen proyeksi menurut citra sebagai berikut:

$$
L P_{p}=f \times L T_{p}
$$


dimana, $L P_{p}$ adalah luas panen proyeksi menurut citra (ha) dan $L T_{p}$ adalah luas lahan sawah menurut citra (ha). Setelah luas panen proyeksi menurut citra telah ditentukan, maka selanjutnya dapat ditentukan produksi padi proyeksi menurut citra dengan cara berikut.

$$
P_{p}=L P_{p} \times Y / 10
$$

Produktivitas padi menurut BPS dijadikan acuan dalam penentuan proyeksi produksi padi menurut citra. Dimana $P_{p}$ merupakan produksi proyeksi menurut citra (ton) dan $Y$ merupakan produktivitas padi menurut data BPS dalam satuan kwintal.

9. Analisis Proyeksi Perubahan Luas Sawah dan Dampak Terhadap Ketahanan Pangan di Kecamatan Pallangga

Analisis proyeksi perubahan luas sawah dan dampak terhadap ketahanan pangan dilakukan dengan membandingkan jumlah beras yang dapat diproduksi dan jumlah beras yang dibutuhkan masyarakat pada tahun mendatang. Jumlah beras yang diproduksi diperoleh dari konversi jumlah gabah pada satu tahun yang sama. Jumlah gabah yang diproduksi dihitung dari luas sawah dikalikan produktivitas sawah dan jumlah musim panen. Luas sawah per tahunnya dan produktivitas lahan didapat dari rata-rata laju perubahan pada tahun 2005 - 2015. Musim panen diseluruh lahan diasumsikan sama yaitu dengan jumlah dua kali panen. Jumlah gabah tersebut dikonversi dengan asumsi bahwa jumlah beras merupakan $62,74 \%$ dari jumlah gabah. Jumlah kebutuhan beras masyarakat didapat dari jumlah penduduk dikalikan jumlah konsumsi beras per kapita. Jumlah penduduk diasumsikan berubah pertahunnya yang didapat dari laju pertumbuhan penduduk tahun 2005 2015 dan konsumsi beras diasumsikan tetap yaitu $139,15 \mathrm{~kg}$ per kapita.

\section{HASIL DAN PEMBAHASAN}

\section{Hasil dan Analisis Proses Pra- pengolahan Citra}

Proses pra-pengolahan citra diawali dengan koreksi geometrik untuk menghasilkan data penginderaan jauh yang sesuai dengan kondisi koordinat sebenarnya dipermukaan tanah. Koreksi geometrik dalam penelitian ini adalah menyamakan posisi (registrasi) antara citra tahun 2005 dengan citra tahun 2016. Penyamaan posisi ini dimaksudkan agar posisi piksel yang sama dapat dibandingkan.

Dari proses koreksi geometrik didapatkan nilai $R M S$ error rata-rata sebesar 0,22. Besarnya RMSE maksimal 0,5. Jadi dapat disimpulkan hasilnya telah memenuhi standar dalam koreksi geometrik. Citra hasil koreksi geometrik dilakukan Image Cropping untuk membatasi daerah penelitian dengan daerah yang bukan daerah penelitian. Pemotongan citra dibatasi oleh data administrasi Kecamatan Pallangga dalam format shapefile dengan memakai tools image analysis pada ArcGis 10.3.

\section{Klasifikasi Penggunaan Lahan}

Klasifikasi penggunaan dilakukan dengan cara mendigitasi secara manual berdasarkan kenampakan pada layar komputer (digitasi on screen). Proses klasifikasi untuk kedua citra menghasilkan lima kelas penggunaan lahan yaitu permukiman, kebun campuran, sawah, jalan dan badan air lahan (Gambar 1 dan Gambar 2). Berikut merupakan penjabaran mengenai ciri-ciri dari kenampakan visual dalam proses interpretasi. 


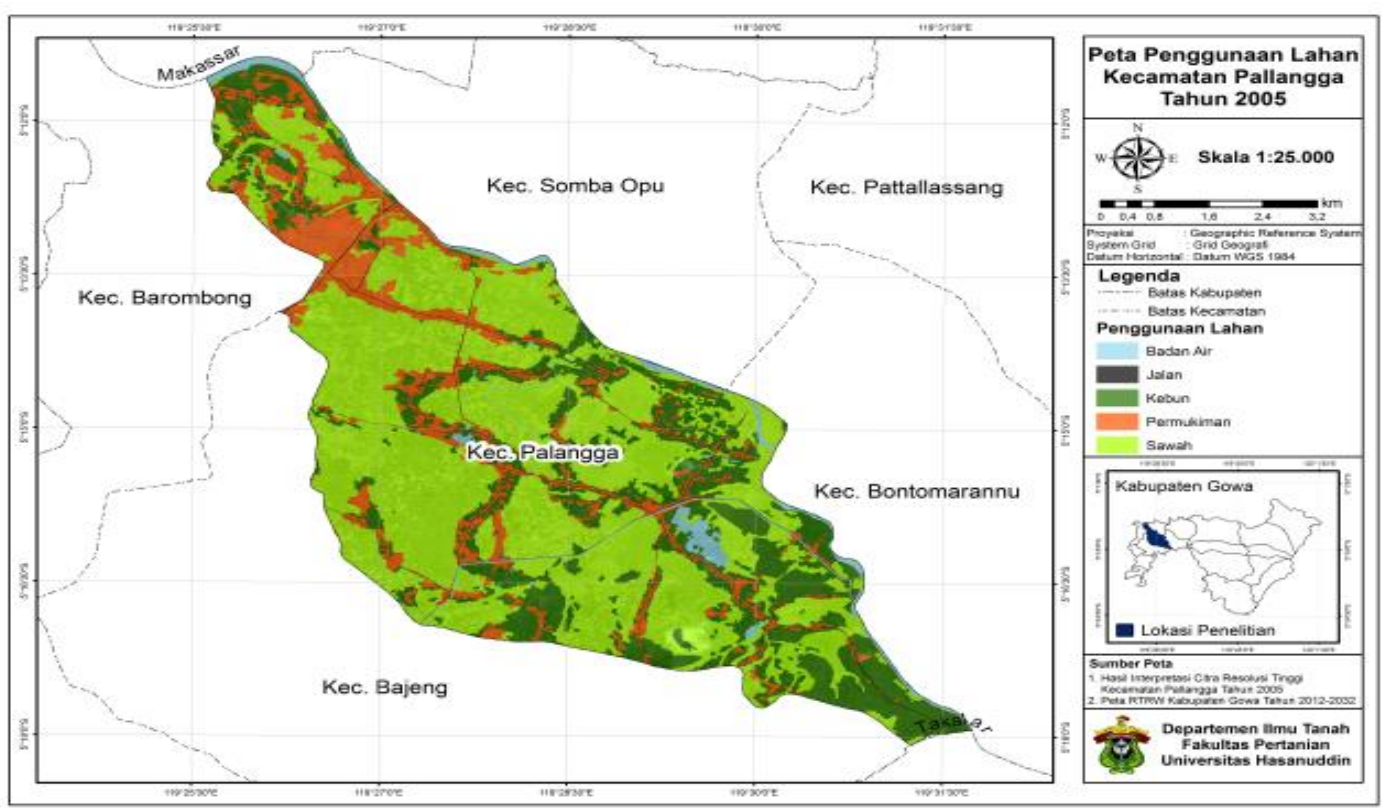

Gambar 1. Peta penggunaan lahan Kecamatan Pallangga tahun 2005

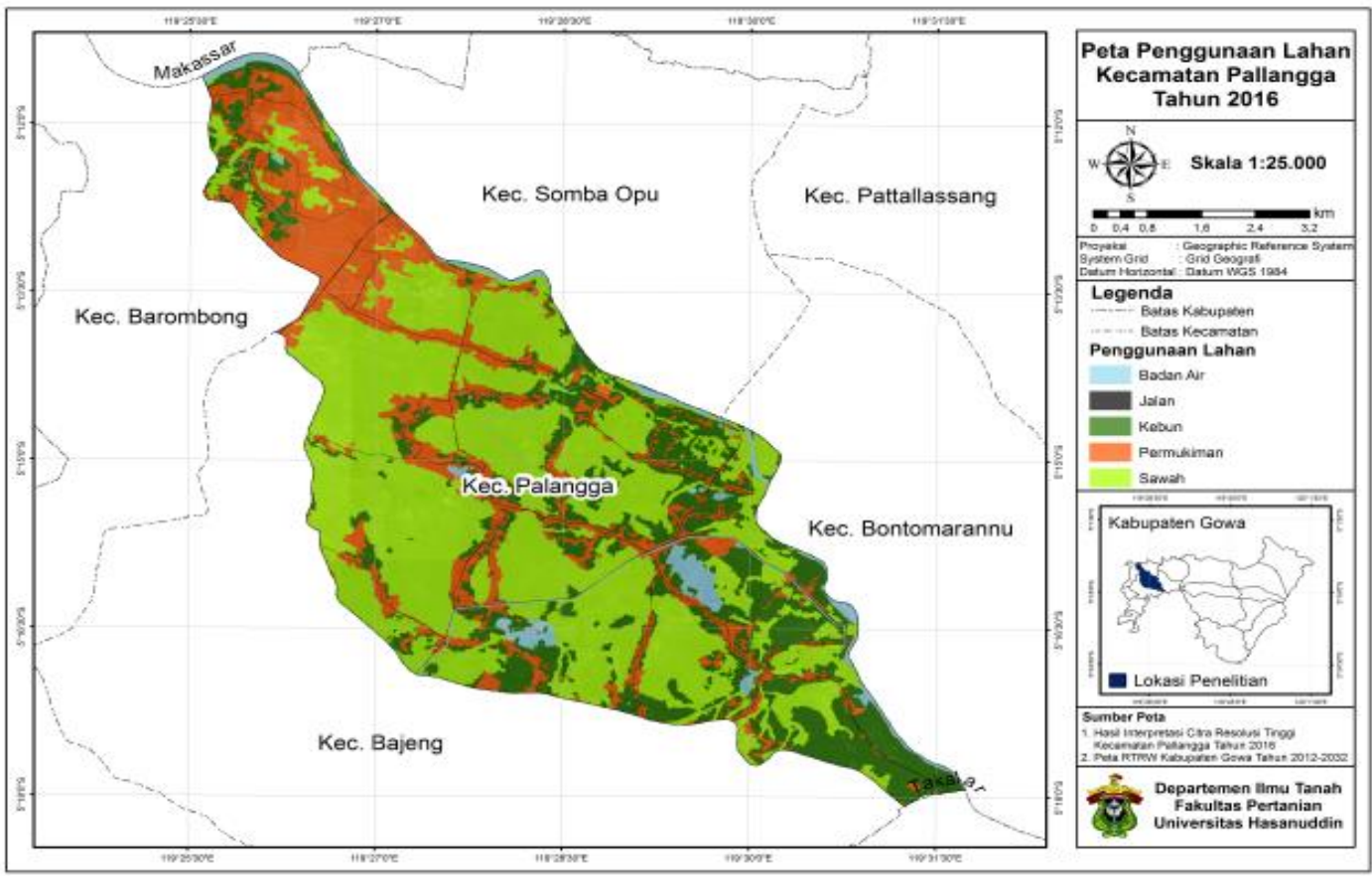

Gambar 2. Peta penggunaan lahan Kecamatan Pallangga tahun 2016

1) Permukiman pada citra memiliki kenampakan dengan rona cerah berbentuk persegi ataupun limas, pola teratur, tekstur kasar dan asosiasi dengan jalan. Permukiman yang dimaksud dalam penelitian ini merupakan lahan terbangun, seperti perumahan atau tempat tinggal, pabrik, sekolah dan bangunan-bangunan sejenisnya.

2) Kebun campuran pada citra memiliki kenampakan berwarna hijau gelap dengan tekstur kasar, rona gelap serta bentuk yang beraturan. Kebun campuran yang dimaksudkan dalam klasifikasi ini adalah lahan yang ditanami selain padi seperti tanaman ubi jalar, jagung, nangka, mangga.

3) Kenampakan sawah pada citra berwarna hijau dan coklat dengan rona cerah, tekstur halus dan bentuk berpetak-petak. Sawah yang dimaksud dalam klasifikasi 
ini adalah lahan yang ditanami padi dan memiliki pematang.

4) Kenampakan jalan dalam citra berbentuk memanjang, akan tetapi sebagian ada yang lurus dan ada yang berkelok-kelok tergantung pada kondisi geomorfologi medan. Warna hitam dengan rona gelap, pola teratur, dan berasosiasi dengan permukiman.

5) Badan air memiliki kenampakan pada citra berwarna biru tua dan coklat dengan rona terang. Adapun badan air berwarna coklat dikarenakan perekaman citra terjadi pada musim hujan sehingga menyebabkan kenaikan sedimentasi dipermukaan. Badan air yang dimaksud dalam penelitian ini adalah lahan yang terendam air, meliputi sungai, irigasi, danau, rawa, embung, dan tambak ikan.

\section{Pengamatan Lapangan (Ground Truth) dan Uji Akurasi Pemetaan}

Uji ketelitian sangat penting dalam setiap hasil penelitian dari setiap jenis data penginderaan jauh. Untuk menguji hasil klasifikasi diperlukan pengecekan lapangan dalam mengecek kebenaran hasil klasifikasi citra terutama pada lokasi meragukan, sehingga tingkat kepercayaan terhadap data yang dihasilkan menjadi lebih kuat. Jumlah sampel pengamatan lapangan sebesar 250 titik yang tersebar merata disetiap kelas penggunaan lahan.

Perhitungan ketelitian hasil klasifikasi dilakukan dengan menghitung nilai overall accuracy dan kappa accuracy dari confusion matrix dengan menggunakan data survey lapangan sebagai referensi validasi. Confusion matrix juga menghasilkan nilai producer accuracy dan user accuracy. Hasil uji akurasi tersebut disajikan pada Tabel 2.

Nilai user accuracy merupakan peluang rata-rata suatu piksel secara aktual mewakili tiap kelas di lapangan. Berdasarkan perhitungan nilai user accuracy menunjukkan bahwa nilai user accuracy terbesar diwakili oleh kelas jalan, permukiman sebesar $100 \%$ yang telah terklasifikasi dengan benar.

Tabel 2. Perhitungan confusion matrix

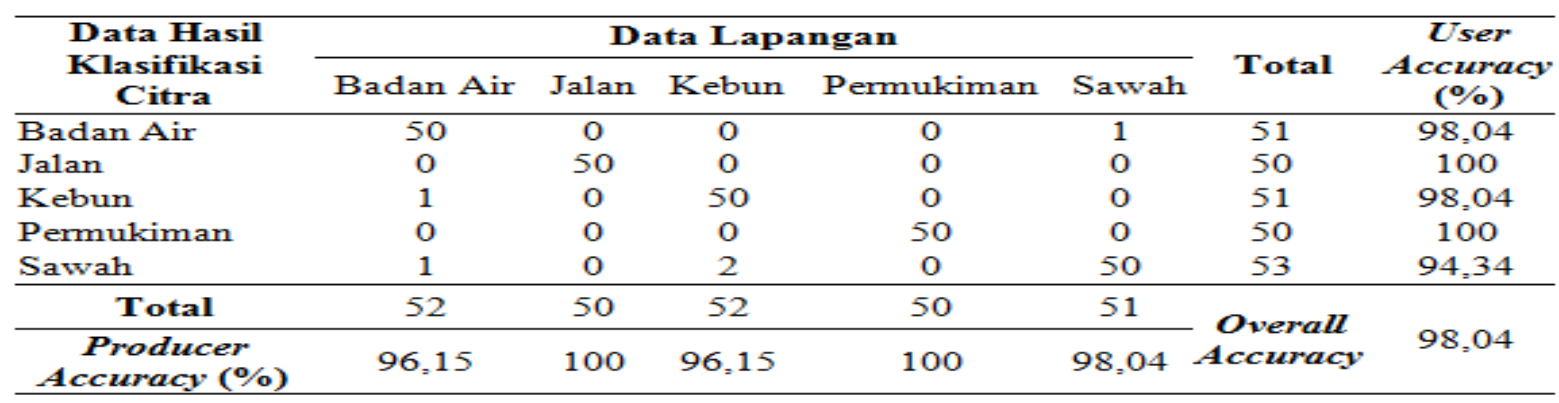

Nilai user accuracy terkecil terdapat pada kelas sawah dengan persentase sebesar 94,34 \% (Tabel 2). Hal ini dikarenakan dalam pengecekan lapangan terdapat tiga titik yang tidak sesuai dengan klasifikasi penggunaan lahan sawah yang telah dilakukan. Ketiga titik ini salah satu diantaranya merupakan penggunaan lahan badan air sedangkan sisanya merupakan penggunaan lahan kebun. Adapun nilai user accuracy penggunaan lahan kebun dan badan air sebesar 98,04 \%, dikarenakan terdapat satu titik dari 50 titik ground truth yang berbeda dengan kelas yang telah diklasifikasikan. Contohnya dalam pengklasifikasian kebun terdapat satu titik sampel ground truth yang merupakan badan air di lapangan. Peneliti salah menginterpretasikan badan air sebagai kebun karena pada citra objeknya berwarna 
hijau dengan rona gelap. Kondisi di lapangan menunjukkan bahwa titik sampel yang diklasifikasikan adalah badan air yang diatasnya tumbuh lumut atau eceng gondok, sehingga tidak nampak air pada citra.

Nilai producer accuracy merupakan nilai setiap piksel pada sebuah kelas telah tepat terklasifikasi. Nilai producer accuracy terbesar terdapat pada kelas jalan dan permukiman dengan persentase sebesar 100 $\%$ telah terklasifikasi dengan benar sedangkan nilai producer accuracy terkecil terdapat pada kelas kebun dan badan air dengan persentase sebesar 96,15\% (Tabel 2). Nilai producer accuracy pada kebun dan badan air sebesar 96,15\% dikarenakan terdapat dua titik sampel di lapangan yang harusnya diklasifikasikan sebagai kelas penggunaan lahan kebun dan badan air.

Hasil perhitungan pada Tabel 2 menunjukkan terdapat 245 titik sampel dari 250 titik sampel terklasifikasi dengan benar. Dengan demikian hasil uji akurasi diperoleh nilai overall accuracy sebesar 98,04\%, dan nilai akurasi kappa sebesar 0,98. Menurut
Green et al. (2000), analisis kappa menghasilkan nilai koefisien kappa yang memiliki rentang kemungkinan dari 0 hingga 1. Berdasarkan perhitungan akurasi kappa tersebut maka hasil klasifikasi ini sudah dapat diterima.

\section{Analisis Perubahan Penggunaan Lahan}

Analisis perubahan penggunaan lahan dilakukan dengan membandingkan peta penggunaan lahan 2005 dengan penggunaan lahan 2016. Perbandingan ini dilakukan untuk mendapat gambaran mengenai perubahan luas lahan dan penyebab perubahan tersebut terjadi. Perbandingan luas penggunaan lahan tahun 2005 dengan penggunaan lahan tahun 2016 disajikan dalam bentuk tabulasi silang pada Tabel 3 . Tabel ini memberikan informasi tentang persentase jumlah luasan dari tahun 20052016 dan mendeskripsikan perubahan penggunaan lahan dari suatu kelas ke menjadi kelas yang lain.

Tabel 3. Tabulasi silang perubahan penggunaan lahan tahun 2005 dan 2016

\begin{tabular}{lcrrrrr}
\hline \multirow{2}{*}{$\begin{array}{c}\text { Penggunaan } \\
\text { ahan 2005 (ha) }\end{array}$} & \multicolumn{4}{c}{ Penggunaan Lahan 2016 (ha) } & \multirow{2}{*}{ Total } \\
\cline { 2 - 6 } & Badan Air & Jalan & Kebun & Permukiman & Sawah & \\
\hline Badan Air & 150,48 & & 7,66 & 1,02 & 1,07 & 160,23 \\
Jalan & & 60,17 & & & & 60,17 \\
Kebun & 28,99 & & $1.017,45$ & 173,69 & 26,47 & $1.246,60$ \\
Permukiman & & & 7,30 & 741,24 & 1,33 & 749,87 \\
Sawah & 17,68 & & 132,86 & 154,71 & $2.754,06$ & $3.059,31$ \\
\hline Total & 197,15 & 60,17 & $1.165,27$ & $1.070,66$ & $2.782,93$ & $\mathbf{5 . 2 7 6 , 1 8}$ \\
\hline
\end{tabular}

Penggunaan lahan badan air mengalami perubahan menjadi kebun, permukiman dan sawah. Badan air yang berubah menjadi kebun lebih luas dari pada penggunaan lahan lain, hal ini dikarenakan pada saat musim kemarau badan air mengalami kekeringan sehingga kini dijadikan sebagai tempat budidaya tanaman hortikultura oleh masyarakat. Penggunaan lahan kebun mengalami perubahan terbesar menjadi permukiman, ini disebabkan adanya kebutuhan lahan oleh masyarakat sejalan dengan bertambahnya penduduk Kecamatan Pallangga. Perubahan ini dapat pula disebabkan adanya faktor ekonomi. Lahan tersebut sudah tidak produktif sehingga dialih fungsikan. Hal ini sesuai dengan teori lokasi model Ricardian Rent, yakni alokasi penggunaan lahan kepada penggunaan yang dapat memberikan surplus ekonomi (land rent) lebih tinggi berdasarkan kualitas lahannya.

Adapun lahan kebun yang berubah menjadi badan air diakibatkan lahan 
tersebut sudah tidak bisa menghasilkan secara ekonomi. Sehingga masyarakat disana mengubahnya menjadi tempat budidaya ikan. Untuk menunjang perekonomian masyarakat disana, hasil dari tambak ikan kemudian dijual. Hal ini sesuai dengan pedapat Rosdinar (2012) yang mengatakan bahwa kondisi sosial ekonomi adalah salah satu pemicu petani melakukan alih fungsi lahan. Mereka merasa tidak mendapat keuntungan ekonomis dari lahan itu.

Penggunaan lahan permukiman beralih fungsi menjadi kebun sebesar 7,30 ha. Perubahan tersebut diakibatkan adanya permukiman yang telah lama ditinggalkan oleh pemiliknya. Lahan tersebut berangsurangsur berubah menjadi lahan kosong yang kini dimanfaatkan untuk bercocok tanam. Penggunaan lahan sawah berubah menjadi permukiman sebesar 154,71 ha diakibatkan adanya kebutuhan lahan oleh penduduk Kecamatan Pallangga. Lahan sawah yang berubah fungsi ini banyak terdapat di daerah utara Kecamatan Pallangga yang berbatasan langsung dengan Kota Makassar.

Perbandingan penggunaan lahan di Kecamatan Pallangga pada tahun 2005 dan tahun 2016 disajikan pada Tabel 4.

Tabel 4. Luas penggunaan lahan Tahun 2005 dan 2016 serta perubahannya.

\begin{tabular}{lccr}
\hline \multirow{2}{*}{ Penggunaan Lahan } & \multicolumn{2}{c}{ Luas (ha) } & \multirow{2}{*}{ Luas Perubahan (ha) } \\
\cline { 2 - 3 } & Tahun 2005 & Tahun 2016 & $(+) 36,92$ \\
Badan Air & 160,23 & 197,15 & 0 \\
Jalan & 60,17 & 60,17 & $(-) 81,33$ \\
Kebun & $1.246,6$ & $1.165,27$ & $(+) 320,79$ \\
Sawah & 749,87 & $1.070,66$ & $(-) 276,38$ \\
\hline Total & $3.059,31$ & $2.782,93$ & 715,39 \\
\hline Ket: $(-)$ berkurang & (+) bertambah & $\mathbf{5 . 2 7 6 , 1 8}$ &
\end{tabular}

Kelas penggunaan lahan yang mengalami penurunan luas areal adalah kelas penggunaan lahan kebun dan sawah. Sawah merupakan kelas yang mengalami penurunan luas areal terbesar, yaitu sebesar 276,38 ha atau 5,24\% dari total wilayah Kecamatan Pallangga. Dari semua kelas penggunaan lahan, yang mengalami peningkatan luas paling tinggi yaitu permukiman. Tahun 2005 permukiman memiliki luas 749,87 ha kemudian pada tahun 2016 meningkat menjadi 1.070,66 ha atau meningkat sebesar 320,79 ha $(6,08 \%)$ (Tabel 4). Peningkatan luas ini disebabkan oleh peningkatan jumlah penduduk dan kepadatan penduduk yang mengakibatkan meningkatnya kebutuhan akan lahan. Data BPS menunjukkan kepadatan penduduk Kecamatan Pallangga mengalami peningkatan dari 2.351 jiwa per kilometer persegi tahun 2014 menjadi 2.428 jiwa per kilometer persegi pada tahun 2015, dengan laju pertumbuhan penduduk pertahun sebesar 4,10 \% (BPS, 2016).

Selain itu, Kecamatan Pallangga kini menjadi salah satu kecamatan yang pembangunannya berkembang pesat. Sehubungan dengan hal tersebut Kecamatan Pallangga merupakan salah satu tempat pengembangan perumahan. Di Kecamatan Pallangga terdapat pula salah satu sekolah pemerintahan yaitu Sekolah Tinggi Pemerintahan Dalam Negeri terletak di Desa Kampili. Oleh sebab itu, konversi lahan oleh masyarakat di Kecamatan Pallangga ini terus-menerus dilakukan.

\section{Analisis Laju Konversi Lahan Sawah}

Pertambahan jumlah penduduk berarti juga peningkatan kebutuhan lahan. Karena lahan tidak dapat bertambah, maka yang terjadi adalah perubahan penggunaan lahan yang cenderung menurunkan proporsi lahan-lahan yang sebelumnya merupakan penggunaan lahan pertanian menjadi lahan non pertanian. 
Penggunaan lahan sawah di Kecamatan Pallangga pada tahun 2005 sebesar 3.059,31 ha atau 57,98 \% dari total luas areal Kecamatan Pallangga. Namun pada tahun 2016 mengalami penurunan sebesar 305,25 ha atau 9,98\% dari total luas penggunaan lahan sawah 2005. Penurunan jumlah luasan ini terjadi karena sawah telah terkonversi menjadi penggunaan lahan lain (Tabel 5).

Tabel 5. Perubahan penggunaan lahan sawah dari tahun 2005 ke 2016

\begin{tabular}{|c|c|c|}
\hline Penggunaan Lahan & Terkonversi.IIenjadi & Luas (ha) \\
\hline & BadanA Air & 17,68 \\
\hline \multirow[t]{2}{*}{ Savah } & Keboun & 132,86 \\
\hline & Permuliman & 154,71 \\
\hline & Jumlah & 30,25 \\
\hline
\end{tabular}

Konversi lahan sawah yang memiliki luas perubahan terbesar menjadi kelas penggunaan lain yaitu perubahan menjadi kelas permukiman sebesar $50,68 \%$ dari total luas perubahan lahan sawah di Kecamatan Pallangga. Menurut Nurwadjedi (2011), konversi lahan secara seketika umumnya terjadi di wilayah sekitar urban, yakni berubah menjadi daerah permukiman atau kawasan industri. Kecamatan Pallangga merupakan wilayah peri urban yang berbatasan langsung dengan Kota Makassar yang terus berkembang. Menurut Tambunan (2008) yang dikutip dari Octora (2014), konversi lahan sawah menjadi daerah permukiman dan kawasan industri umunya terjadi di wilayah-wilayah sentra produksi beras yang posisinya dekat dengan jalan raya, Kecamatan Pallangga merupakan daerah yang dilalui/dilewati jalan arteri yang menghubungkan antara Kabupaten Gowa dan Kabupaten Takalar dan Kabupaten Jeneponto.

Faktor yang mempengaruhi berkurangnya lahan pertanian antara lain yaitu peningkatan jumlah penduduk. Sehingga dengan sendirinya permukiman akan bertambah. Adanya dinamika perkotaan dimana letak Kecamatan
Pallangga berada dekat dengan Kota Makassar sehingga pembangunan daerah ke perkotaan tidak dapat dihindari. Pada hasil klasifikasi citra dapat dilihat permukiman bergerak pesat ke arah utara yang berbatasan dengan kota Makassar (Gambar 2). Winoto (2005) yang dikutip dari Irsalina (2010) mengemukakan bahwa lahan pertanian yang paling rentan terhadap alih fungsi adalah sawah. Hal tersebut disebabkan oleh pembangunan prasarana dan sarana pemukiman, kawasan industri, dan sebagainya cenderung berlangsung cepat di wilayah bertopografi datar, dimana pada wilayah dengan topografi seperti itu (terutama di Kecamatan Pallangga) ekosistem pertaniannya dominan areal persawahan.

Perubahan penggunaan lahan sawah menjadi kebun sebesar 132,86 ha atau 43,52 $\%$ dari total luas perubahan lahan sawah di Kecamatan Pallangga. Hal ini bisa terjadi karena adanya sistem penggunaan lahan sawah bergantian dengan tanaman palawija pada waktu tertentu. Pada masa setelah panen, lahan sawah diberakan terlebih dahulu sebelum ditanami padi kembali. Hal ini bertujuan untuk mengembalikkan kesuburan dan unsur hara tanah. Selama diberakan, lahan sawah digunakan untuk menanam tanaman palawija seperti kacang tanah, kacang panjang, dan ubi jalar.

Perubahan penggunaan lahan sawah menjadi badan air sebesar 17,68 ha atau 5,79 $\%$ dari total luas perubahan lahan sawah di Kecamatan Pallangga. Sawah yang sebelumnya ditahun 2005 berubah menjadi badan air ditahun 2016, diakibatkan terjadinya penggerutan atau pengambilan tanah pada lokasi tersebut. Lahan tersebut berubah menjadi sebuah lubang, yang pada musim hujan akan mengakibatkan lahan tersebut terisi air, sehingga pada citra diklasifikasikan sebagai badan air. Namun ada beberapa titik dilokasi penelitian yang dahulunya sawah kini dijadikan embung. Embung ini digunakan untuk menampung kelebihan air hujan dimusim hujan dan dimanfaatkan pada musim kemarau untuk mengairi lahan pertanian. 
Menurut Pasandaran (2006), permintaan lahan cenderung tinggi pada kawasan pertanian yang sudah berkembang dengan sasaran konsumen di pinggiran kota. Konversi lahan sawah bersifat irreversible, menurunnya produksi padi akibat konversi lahan sawah bersifat permanen. Semakin tinggi lahan yang dikonversi, maka semakin tinggi pula kerugian yang ditimbulkannya (Nurwadjedi 2011).

Perubahan penggunaan lahan sawah yang terjadi dari tahun 2005 hingga tahun 2016 akan berdampak terhadap turunnya produksi pertanian. Menurut Perda nomor 15 tahun 2012 tentang Rencana Tata Ruang Wilayah (RTRW) Kabupaten Gowa tahun 2012 - 2032 yang salah satu kebijakan dan strategi penataan ruang Kabupaten Gowa dalam pengembangan infrastruktur wilayah guna mendukung kehidupan sosial ekonomi masyarakat dalam menjalin ketersediaan pangan nasional adalah dengan pengembangan kawasan budidaya. Pada pasal 31 dalam Perda No. 15/2012 telah ditetapkan rencana pola ruang wilayah Kabupaten Gowa meliputi kawasan lindung dan kawasan budidaya.

Pola ruang yang terdapat di Kecamatan Pallangga berdasarkan RTRW Kabupaten Gowa terdiri atas kawasan budidaya pertanian lahan basah, kawasan budidaya pertanian lahan kering, kawasan perairan, dan kawasan permukiman. Kawasan budidaya pertanian lahan basah memilki luas yang terbesar yaitu $66,49 \%$ $(3.508,2$ ha) dari total luas wilayah Kecamatan Pallangga dan luas yang terkecil adalah kawasan perairan yaitu 1,90 \% $(100,48$ ha) dari total luas wilayah Kecamatan Pallangga.

Hasil tumpang susun penggunaan lahan sawah tahun 2016 dengan RTRW Kabupaten Gowa tahun 2012 - 2032, menunjukkan bahwa terdapat $2.553,38$ ha penggunaan lahan sawah yang konsisten atau sama dengan pengalokasian penggunaan lahan menurut pola ruang RTRW Kabupaten Gowa. Adapun luas yang inkonsisten sebesar 229,55 ha. Penggunaan lahan sawah pada tahun 2016 berbeda dengan pengalokasian penggunaan lahan menurut pola ruang RTRW untuk kawasan budidaya pertanian lahan kering sebesar 0,72 $\%$ dari total luas sawah. Dan kawasan perairan sebesar $0,14 \%$ dari total luas sawah, serta kawasan permukiman sebesar 7,39\% dari total luas sawah (Tabel 6). Hal ini mengindikasikan bahwa penggunaan lahan sawah tahun 2016 tidak sesuai dengan pola ruang RTRW Kabupaten Gowa sebesar $8,25 \%$ dari total luas sawah Kecamatan Pallangga tahun 2016.

Tabel 6. Luas hasil tumpang susun penggunaan lahan sawah tahun 2016 dengan alokasi RTRW Kabupaten Gowa tahun 2012 2032

\begin{tabular}{|c|c|c|}
\hline $\begin{array}{l}\text { Penggunaan Lahan } \\
2016\end{array}$ & Alokasi RTRW & Luas (ha) \\
\hline \multirow{5}{*}{ Sawah } & Kawasan Budidaya Pertanian Lahan Basah & $2.553,38$ \\
\hline & Kawasan Budidaya Pertanian Lahan Kering & 19,98 \\
\hline & Kawasan Perairan & 3,98 \\
\hline & Kawasan Permukiman & 205,59 \\
\hline & Jumlah & $2.782,93$ \\
\hline
\end{tabular}

\section{Analisis Kebutuhan Beras Per Kapita Kecamatan Pallangga}

Laju alih fungsi lahan sawah ke sektor non pertanian maupun komoditi selain padi sawah tentu akan dapat mengancam ketahanan pangan yang berdampak terhadap turunnya produksi pertanian. Berdasarkan penelitian yang dilakukan oleh Sulistyawati (2014), kerugian akibat adanya alih fungsi lahan sawah di Kabupaten Cianjur selama kurun waktu 10 tahun (2004 - 2013) menyebabkan penurunan produksi padi sebesar 33.172,15 ton.

Jumlah lahan sawah yang terus menurun akan menurunkan produksi beras yang dihasilkan. Hal ini sangat berbanding terbalik dengan adanya jumlah penduduk yang setiap tahun terus meningkat. Dalam jangka kurun waktu 10 tahun selama periode tahun 2005 - 2015 penduduk Kecamatan 
Pallangga mengalami kenaikan sebesar 49,63\%, atau bertambah sebanyak 38.843 jiwa dengan rata-rata pertumbuhan penduduk 4,20 \% per tahun. Hal ini mengindikasikan bahwa meningkatnya jumlah penduduk harus disertai dengan jumlah bahan pangan yang tersedia. Besarnya jumlah penduduk terkait langsung dengan penyediaan pangan.

Untuk melihat kecukupan pangan atau ketahanan pangan lokal di Kecamatan Pallangga, dilakukan perbandingan antara jumlah produksi beras (ton) ditahun 2016 dengan jumlah penduduk pada tahun 2017. Hasil dari pengolahan data tersebut dibandingkan dengan angka ketetapan dari Badan Ketahanan Pangan Kementerian Pertanian mengenai angka konsumsi beras yaitu sebesar $139,15 \mathrm{~kg} /$ tahun atau 0,14 ton/tahun.

Ketahanan pangan lokal yang dihitung dalam penelitian ini hanya dengan asumsi bahwa masyarakat di Kecamatan Pallangga hanya mengkonsumsi beras sebagai makanan pokok. Untuk perhitungan kebutuhan beras dengan asumsi bahwa jumlah produksi beras tahun 2016 diperoleh dari hasil proyeksi luas panen dan produksi beras menurut klasifikasi citra berdasarkan produktivitas dari data statistik pertanian BPS.

Sebelum menentukan luas panen, terlebih dahulu dicari rasio dari luas panen sawah terhadap luas lahan sawah berdasarkan data statistik BPS. Cara penentuan proyeksi luas panen sawah menurut citra berdasarkan data statistik pertanian BPS yaitu dengan menentukan rasio antara luas panen dan luas lahan sawah menurut data BPS terlebih dahulu. Luas panen menurut citra dihitung dari rasio antara luas panen dan lahan sawah menurut data BPS dikalikan dengan luas sawah menurut citra (hektar). Selanjutnya untuk menentukan jumlah produksi padi proyeksi menurut citra dihitung dari luas panen menurut citra dikalikan dengan produktivitas padi menurut data BPS dalam satuan kuintal.
Rumus untuk menghitung kebutuhan beras per kapita, didapatkan bahwa hasil produksi beras di tahun 2016 dapat memenuhi kebutuhan penduduk Kecamatan Pallangga sebesar 124.484 jiwa di tahun 2017. Hal ini dikarenakan angka hasil pengolahan data sebesar 172,64 $\mathrm{kg} / \mathrm{kapita} /$ tahun lebih tinggi daripada angka ketetapan Badan Ketahanan Pangan Kementerian Pertanian sebesar 139,15 $\mathrm{kg} / \mathrm{kapita} / \mathrm{tahun}$. Angka tersebut menunjukkan bahwa di Kecamatan Pallangga untuk konsumsi beras adalah $172,64 \mathrm{~kg} / \mathrm{kapita} / \mathrm{tahun}$. Dengan demikian, dari sisi kecukupan pangan (beras), Kecamatan Pallangga sudah mampu memenuhi kebutuhan berasnya sendiri tanpa harus tergantung pada pasokan beras dari daerah lain.

\section{Analisis Proyeksi Perubahan Luas Sawah dan Dampak Terhadap Ketahanan Pangan di Kecamatan Pallangga}

Dampak alih fungsi lahan yang terus terjadi akan mengancam ketahanan pangan yang ada di Kecamatan Pallangga. Permasalahan ketahanan pangan ini akan menurunkan jumlah produksi beras. Luas lahan sawah yang terus menurun akan menurunkan produksi beras yang dihasilkan. Hal ini sangat berbanding terbalik dengan adanya jumlah penduduk yang setiap tahun terus meningkat. Simulasi ini dilakukan dengan membandingkan jumlah beras yang dapat diproduksi dan jumlah beras yang dibutuhkan masyarakat pada tahun mendatang.

Jumlah beras yang diproduksi diperoleh dari konversi jumlah gabah pada satu tahun yang sama. Jumlah gabah yang diproduksi dihitung dari luas sawah dikalikan produktivitas sawah dan jumlah musim panen. Luas sawah per tahunnya diasumsikan berubah dengan laju sebesar $0,03 \%$ dan produktivitas lahan diasumsikan berubah dengan laju 2,49\%. Nilai tersebut didapat dari rata-rata laju perubahan pada tahun 2005 sampai tahun 2015. Musim panen diseluruh lahan diasumsikan sama 
yaitu dengan jumlah dua kali panen. Jumlah gabah tersebut dikonversi dengan asumsi bahwa jumlah beras merupakan $62,74 \%$ dari jumlah gabah. Jumlah kebutuhan beras masyarakat didapat dari jumlah penduduk dikalikan jumlah konsumsi beras per kapita. Jumlah penduduk diasumsikan berubah pertahunnya dengan laju sebesar 4,20\% dan konsumsi beras diasumsikan tetap yaitu $139,15 \mathrm{~kg}$ per kapita. Berdasarkan asumsi tersebut maka perkiraan luas sawah dan dampak terhadap ketahanan pangan dapat dilihat pada Tabel 7.

Hasil analisis kebutuhan beras per kapita menunjukkan tahun 2017 Kecamatan Pallangga surplus dalam penyediaan beras terhadap penduduknya. Tabel 7 menunjukkan bahwa Kecamatan Pallangga dapat memenuhi ketersediaan beras masyarakatnya sampai pada tahun 2019. Namun pada tahun 2020 produksi beras tidak dapat memenuhi kebutuhan beras di Kecamatan Pallangga.

Tabel 7. Proyeksi perubahan luas lahan dan dampak terhadap ketahanan pangan di Kecamatan Pallangga.

\begin{tabular}{cccrrr}
\hline Tahun & $\begin{array}{c}\text { Luas } \\
\text { Sawah } \\
\text { (ha) }\end{array}$ & $\begin{array}{c}\text { Jumlah } \\
\text { Penduduk } \\
\text { (Jiwa) }\end{array}$ & $\begin{array}{c}\text { Ketersedian } \\
\text { beras (ton) }\end{array}$ & $\begin{array}{c}\text { Konsumsi } \\
\text { Beras (ton) }\end{array}$ & $\begin{array}{c}\text { Selisih } \\
\text { Beras } \\
\text { (ton) }\end{array}$ \\
\hline 2016 & 2.737 & 122.034 & 21.032 & 16.981 & 4.051 \\
2017 & 2.736 & 127.159 & 20.502 & 17.694 & 2.808 \\
2018 & 2.736 & 132.500 & 19.986 & 18.437 & 1.549 \\
2019 & 2.735 & 138.065 & 19.482 & 19.212 & 271 \\
2020 & 2.734 & 143.864 & 18.992 & 20.019 & -1.027 \\
2021 & 2.733 & 149.906 & 18.513 & 20.859 & -2.346 \\
2022 & 2.732 & 156.202 & 18.047 & 21.736 & -3.689 \\
2023 & 2.731 & 162.762 & 17.592 & 22.648 & -5.056 \\
2024 & 2.731 & 169.598 & 17.149 & 23.600 & -6.451 \\
2025 & 2.730 & 176.722 & 16.717 & 24.591 & -7.874 \\
2026 & 2.729 & 184.144 & 16.296 & 25.624 & -9.328 \\
2027 & 2.728 & 191.878 & 15.885 & 26.700 & -10.815 \\
2028 & 2.727 & 199.937 & 15.485 & 27.821 & -12.336 \\
2029 & 2.727 & 208.334 & 15.095 & 28.990 & -13.895 \\
2030 & 2.726 & 217.084 & 14.715 & 30.207 & -15.493 \\
\hline
\end{tabular}

Ketersediaan produksi beras lebih kecil dari kebutuhan beras pada tahun tersebut, yaitu diperkirakan sebesar 18.992 ton dengan kebutuhan beras yang diprediksi sebesar 20.019 ton. Sehingga pada tahun tersebut akan terjadi kekurangan beras yaitu sebesar 1.027 ton.

Jika alih fungsi lahan sawah terusmenerus terjadi ini akan mengakibatkan ketersediaan beras menurun. Hasil proyeksi perubahan luas lahan sawah (tabel 7) menunjukkan bahwa pada tahun 2030 kekurangan beras sebesar 15.493 ton. Pada tahun 2030 ketersediaan beras untuk Kecamatan Pallangga sebesar 15.493 ton.

\section{KESIMPULAN}

Berdasarkan hasil penelitian yang telah dilakukan, maka dapat disimpulkan bahwa:

1. Luas lahan sawah Kecamatan Pallangga pada tahun 2005 seluas 3.059,31 ha atau $57,98 \%$ dari total luas areal Kecamatan Pallangga dan pada tahun 2016 mengalami penurunan sebesar 305,25 ha atau $9,98 \%$ dari total luas penggunaan lahan sawah 2005.

2. Angka ketetapan beras untuk ketersediaan beras terkait Ketahanan Pangan Lokal adalah 139,15 $\mathrm{kg} / \mathrm{kapita} / \mathrm{tahun}$. Sedangkan dari hasil pengolahan data mencapai 172,64 $\mathrm{kg} / \mathrm{kapita} /$ tahun. Jadi, dapat disimpulkan produksi beras tahun 2016 di Kecamatan Pallangga surplus dan dapat memenuhi kebutuhan penduduknya sebesar 124.484 jiwa di tahun 2017. Namun hasil perkiraan perubahan luas sawah dan dampaknya terhadap ketahanan pangan adalah produksi beras tidak dapat memenuhi kebutuhan pada tahun 2020 dengan kekurangan sebesar 1.027 ton. 


\section{DAFTAR PUSTAKA}

Asia, M.I. M. 2015. Perubahan Penggunaan Lahan Pertanian Wilayah Peri Urban Periode 2009-2014 Kecamatan Pallangga Kabupaten Gowa. Skripsi. Makassar: Fakultas Pertanian Universitas Hasanuddin.

Badan Pusat Statistik. 2016. Statistik Daerah Kecamatan Pallangga 2015. Kabupaten Gowa: Badan Pusat Statistik Kabupaten Gowa.

Bagian Organisasi dan Tatalaksana Pemerintah Daerah Kabupaten Gowa Sulawesi Selatan. 2015. Laporan Kinerja Pemerintah Kabupaten Gowa Tahun 2014.

Green, E. P., Mumby, P.J., Edwards, A.J., Clark, C.D. 2000. Remote Sensing Handbook for Tropical Coastal Management. Paris (FR): UNESCO Publishing.

Hidayati, I. N. 2013. Pengaruh Ketinggian dalam Analisis Kemasuk-Akalan (Plausibility Function) untuk Optimalisasi Klasifikasi Penggunaan Lahan. Globe. 15(1): 1 - 11.

Irsalina, S. 2010. Analisis Alih Fungsi Lahan Sawah Di Kabupaten Langkat. Skripsi. Medan: Fakultas Pertanian Universitas Sumatera Utara.

Khoiriah, I.F., dan Nur, M. F. 2012. Perbandingan Akurasi Klasifikasi Penutup Lahan Hasil Penggabungan Citra ALOS AVNIR-2 dan ALOS PALSAR pada Polarisasi Berbeda dengan Transformasi Wavelet. Jurnal Bumi Indonesia. 1(2).

Khorram, S., dan Morisette, J. T. 2000. Accuracy assessment curves for satellite-based change detection.
Photogrammetric Engineering and Remote Sensing. 66(7): 875-880.

Nurwadjedi. 2011. Indeks Keberlanjutan Lahan Sawah Untuk Mendukung Penataan Ruang: Studi Kasus Di Pulau Jawa. Disertasi. Bogor: Program Pasca Sarjana Institut Pertanian Bogor.

Octora, W. 2014. Analisis Luas Lahan Sawah Berbasis Citra Modis di Provinsi Jawa Barat Tahun 20022012. Skripsi. Bogor: Fakultas Pertanian Institut Pertanian Bogor.

Pasandaran, E. 2006. Alternatif Kebijakan Pengendalian Konversi Lahan Sawah Beririgasi di Indonesia. Jurnal Litbang Pertanian 25(4): 123-129.

Rosdinar, R. 2012. Pengaruh Luas Lahan Terhadap Produksi Padi Di Kecamatan Kalijati Kabupaten Subang. Skripsi. Bandung: Fakultas Ekonomi Universitas Islam Bandung.

Sinaga, R. 2004. Pemanfaatan Penginderaan Jauh dan Sistem Informasi Geografi dalam Mengkaji Perubahan Penggunaan lahan Kecamatan Umbulharjo tahun 1993-2004. Laporan Tugas Akhir. Fakultas Geografi, Universitas Gadjah Mada Yogyakarta.

Sulistyawati, D. A. 2014. Analisis Dampak Alih Fungsi Lahan Pertanian Terhadap Ketahanan Pangan di Kabupaten Cianjur (Studi Kasus: Desa Sukasirna, Kecamatan Sukaluyu). Skripsi. Bogor: Departemen Ekonomi Sumberdaya dan Lingkungan Fakultas Ekonomi dan Manajemen, Institut Pertanian Bogor. 